\title{
PENTINGNYA EVALUASI SETELAH PEMBERIAN ASUHAN KEPERAWATAN
}

\author{
Elisa Claudia Simanjuntak / 181101114 \\ elclaudia02@gmail.com
}

\begin{abstract}
ABSTRAK
Latar Belakang : Menurut penelitian, kinerja keperawatan pada umumnya belum memenuhi standar asuhan keperawatan, terutama dalam hal pengkajian keperawatan, perumusan diagnosis, perencanaan, pelaksanaan, dan evaluasi yang semuanya masih dalam rata-rata cukup. Hal ini sangat mempengaruhi kemajuan kondisi pasien.

Tujuan : Tujuan penulisan kajian ini adalah untuk mengetahui pentingnya evaluasi setelah dilakukan pemberian asuhan keperawatan.

Metode : Metode yang digunakan dalam kajian ini adalah literature review, yaitu dengan cara menganalisis, mengeksplorasi serta mengkaji bebas jurnal dan buku teks yang membahas tentang evaluasi asuhan keperawatan.

Hasil : Hasil kajian menunjukkan bahwa sambil memberi asuhan keperawatan, perawat dapat mengevaluasi kondisi pasien. Hasil evaluasi yang didapat digunakan untuk mengkaji ulang kondisi pasien.

Pembahasan : Tahap evaluasi dari proses keperawatan mengukur respons pasien terhadap tindakan keperawatan dan kemajuan pasien ke arah pencapaian tujuan. Selama evaluasi, perawat memutuskan apakah langkah proses keperawatan sebelumnya telah efektif dengan melihat respon pasien.
\end{abstract}

Kata Kunci : Evaluasi, Asuhan Keperawatan, Perawat. 


\section{Latar Belakang}

Proses keperawatan adalah suatu pendekatan dalam pemecahan masalah, sehingga perawat dapat merencanakan dan memberikan asuhan keperawatan (Potter and Perry, 1997). Proses keperawatan akan sangat membantu perawat dalam merencanakan asuhan keperawatan yang tepat dan berkualitas. Tahap terakhir dari proses keperawatan adalah evaluasi. Pada tahap ini, perawat menilai apakah pasien mengalami kemajuan setelah pemberian asuhan keperawatan atau tidak. Namun, sering sekali tahap evaluasi maupun tahap lain dalam proses keperawatan tidak dilakukan dengan baik oleh perawat.

Menurut penelitian, kinerja keperawatan pada umumnya belum memenuhi standar asuhan keperawatan, terutama dalam hal pengkajian keperawatan, perumusan diagnosis, perencanaan, pelaksanaan, dan evaluasi yang semuanya masih dalam rata-rata cukup. Hal ini sangat mempengaruhi kemajuan kondisi pasien. Oleh karena itu, semua tahap dalam proses keperawatan perlu dilakukan dengan baik agar tujuan dilakukannya asuhan keperawatan dapat tercapai.

\section{Tujuan}

Pengkajian ini dilakukan untuk mengetahui pentingnya evaluasi setelah dilakukan pemberian asuhan keperawatan.

\section{Metode}

Metode yang digunakan dalam kajian ini adalah literature review, yaitu dengan cara menganalisis, mengeksplorasi serta mengkaji bebas jurnal dan buku teks yang membahas tentang evaluasi asuhan keperawatan. Referensi berupa jurnal dan buku teks yang digunakan adalah sebanyak 14 . Jurnal yang digunakan sebagai referensi dalam tulisan ini diterbitkan dalam kurun waktu 10 tahun terakhir.

\section{Hasil}

Evaluasi dilakukan untuk melihat bagaimana respon pasien terhadap asuhan keperawatan yang diterimanya. Sambil memberi asuhan keperawatan, perawat dapat mengevaluasi kondisi pasien. Hasil evaluasi yang didapat digunakan untuk mengkaji ulang kondisi pasien. Nantinya data yang dikumpulkan dapat digunakan untuk evaluasi selanjutnya. Setelah tujuan dari evaluasi telah terpenuhi, perawat dapat 
mengetahui bahwa asuhan keperawatan yang diberikan telah berhasil dan pasien mengalami kemajuan.

\section{Pembahasan}

Evaluasi merupakan tahap akhir dari proses keperawatan. Namun, evaluasi dapat dilakukan pada setiap tahap proses keperawatan. Tahap evaluasi dari proses keperawatan mengukur respons pasien terhadap tindakan keperawatan dan kemajuan pasien ke arah pencapaian tujuan. Data dikumpulkan dengan dasar berkelanjutan untuk mengukur perubahan dalam fungsi, dalam kehidupan sehari-hari, dan dalam ketersediaan atau penggunaan sumber eksternal (Carnevali \& Thomas, 1993).

Selama evaluasi, perawat memutuskan apakah langkah proses keperawatan sebelumnya telah efektif dengan melihat respon pasien.

Dalam proses keperawatan ada beberapa tipe evaluasi yang dilakukan, yaitu:

1. Evaluasi Tujuan

Fokus pada hasil, tujuan, dan tingkat kepuasan pasien terhadap asuhan keperawatan.

2. Evaluasi Proses
Fokus pada bagaimana asuhan keperawatan yang diberikan.

3. Evaluasi Struktur

Fokus pada persiapan lingkungan dimana asuhan keperawatan diberikan.

Adapun jenis-jenis evaluasi dalam proses keperawatan, yaitu:

1. Evaluasi Formatif

Evaluasi yang menggambarkan hasil observasi dan analisis perawat terhadap respon pasien setelah asuhan keperawatan.

2. Evaluasi Sumatif

Evaluasi yang menjelaskan perkembangan kondisi pasien dengan menilai apakah hasil yang diharapkan telah tercapai.

\section{Penutup}

Evaluasi merupakan tahap akhir dalam proses keperawatan. Evaluasi dilakukan untuk melihat bagaimana respon pasien setelah menerima asuhan keperawatan. Perawat harus bertanggung gugat dan bertanggung jawab untuk mengevaluasi setiap kemajuan dan memperbaiki kualitas asuhan keperawatan agar tujuan setelah dilakukan asuhan keperawatan dapat tercapai. 


\section{Referensi}

Ali, Z. (2001). Dasar-dasar keperawatan profesional. Jakarta: Penerbit EGC.

Astar, F. dkk. (2018). Pengaruh Pelayanan Asuhan Keperawatan Terhadap Kepuasan Pasien di Puskesmas Takalala Kabupaten Soppeng. Journal of Management. 1(2): 33-57.

Deswani. (2009). Proses Keperawatan dan Berpikir Kritis. Jakarta: Salemba Medika.

Haryanto. (2008). Konsep Dasar Keperawatan dengan Pemetaan Konsep (Concept Mapping). Jakarta: Salemba Medika.

Hastuti, W. \& Widiyaningsih. (2017). Aplikasi Concept Mapping Dalam Pemberian Asuhan Keperawatan di Stase Maternitas. Jurnal Keperawatan dan Pemikiran Ilmiah. 3 (3): 19-26.

Lismidar, H. dkk. (1990). Proses Keperawatan. Jakarta: UI Press.
Maryam, Siti, dkk. (2006). Buku Ajar Berpikir Kritis dalam Proses Keperawatan. Jakarta: EGC.

Potter \& Perry. (2005). Buku Ajar Fundamental Keperawatan: Konsep, Proses, dan Praktik Edisi 4. Jakarta: EGC.

Sedyowinarso, M. dkk. (2012). Evaluasi Pelaksanaan Sistem Pemberian Asuhan Keperawatan di Ruang Rawat Inap Terhadap Kinerja Perawat. Berita Kedokteran Masyarakat. 28(1): 1-6.

Simamora, R.H. (2009). Dokumentasi Proses Keperawatan. Jember: Jember University Press.

Simamora, R.H. (2010). Komunikasi dalam Keperawatan. Jember: Jember University Press.

Simamora, R. H. (2008). Peran Manajer dalam Pembinaan Etika Perawat Pelaksana dalam Peningkatan Kualitas Pelayanan Asuhan Keperawatan. Jurnal IKESMA. 4(2).

Tarwoto \& Wartonah. (2012). Kebutuhan Dasar Manusia dan Proses 
Keperawatan. Jakarta: Salemba

Medika.

Vaughans, Bennita W. (2013).

Keperawatan Dasar. Yogyakarta:

Rapha Publishing. 